NAGY ANDOR

\title{
A BRASSÓI SZÁSZ TISZTVISELŐK HIVATALBA LÉPÉSEINEK ÁTLAGOS IDŐPONTJAI (1650-1750)*
}

A jelen írásomban a kora újkori brassói (Kronstadt, Braşov) szász tisztviselők karrierútjaira fókuszálva azt vizsgálom, hogy milyen életkorban töltötték be a különböző egyházi és városvezetői hivatalokat egy százéves időszak vonatkozásában. Az időhatárok kijelöléséhez a kútfőtípusok minél gazdagabb bevonásának szándéka vezetett, hiszen a kérdés érdemi megválaszolásának alapvető feltétele a megfelelő adatbőség. Ezen időszaknak a köztörténeti eseményei sem a város egyházi, sem pedig a közigazgatási működésére nem gyakoroltak hatást.

A jelen írás egyik nélkülözhetetlen alapjául Friedrich Wilhelm Stenner (1851-1924) brassói levéltárosnak a város tisztviselőiről szóló hivatali névtára' szolgált, amelyet lehetőségem volt kiegészíteni és az adatokat összevetni Thomas Tartler (1700-1770) prázsmári (Tartlau, Prejmer) lelkésznek a Brassóra vonatkozó, rendkívül részletes kéziratos gyűjtésével. ${ }^{2}$ Itt említem meg a Quellen zur Geschichte der Stadt Kronstadt sorozat köteteinek áttekintését is, amelyet a 19-20. század fordulójától kezdve a szász levéltárosok és történészek adnak ki mindmáig (köztük az egyéni életútra vonatkozó adatokat tartalmazó egykori személyes feljegyzéseket és naplókat). Az egyházi elöljáróságra vonatkozóan említhetem meg Eduard Morresnek (1851-1945) a brassói Fekete-templom Levéltárában őrzött barcasági lelkészekkel kapcsolatos kéziratos gyűjtéseit. ${ }^{3}$ Ezen kívül rendelkezésünkre áll a Honterus Gimnázium matrikulája ${ }^{4}$ is a vizsgált időszakban, ahol nemcsak a diákok és diáktársak beiratkozásait lehet nyomon követni, hanem a különböző fokozatban oktató tanárokat is. Alapvető forrásnak

* A tanulmány elkészítését az NKFIH (OTKA) K 134378 azonosítószámú, a Dualizmus kori parlamentarizmus regionális nézőpontból című pályázat támogatta.

1 Friedrich Stenner: Die Beamten der Stadt Brassó (Kronstadt) von Anfang der städtischen Verwaltung bis auf die Gegenwart. Brassó, Schneider et Feminger 1916.

2 Thomas Tartler: Collectanea zu einer Particulär-Historie von Cronstadt aus unterschiedlichen Dokumenten zusammengebracht. Anno 1741. I. Band. Fortgesetzt und Vermehrt mit einem zweite Bande von Joseph Franz Trausch. A dokumentum mai lelőhelye: Archiv und Bibliothek der Honterusgemeinde Kronstadt (a továbbiakban: AHG) IV.F.1.Tq.100.

3 Eduard Morres: Buzenländer Gedenkbuch 1939. [Kézirat]. Jelzete: AHG I.F.17.; Eduard Morres: Lehrkräfte der Honterusschule (1544-1944) [Kézirat]. Jelzete: AHG I.F.18.

4 Matrikel des ev. Gymnasium A. B. in Kronstadt 1544-1810. [Kézirat]. Jelzete: AHG I.E.145. Emellett az egyes személyek életpálya-alakulásaira is gazdagon fordulnak elő lapszéli utalások is. 
bizonyult Ernst Wagnernek a szász tanári és lelkészi névtára (1700-ig), ${ }^{5}$ valamint az egyetemtörténeti kutatások eredményei, amelyek szintén a rendelkezésünkre állnak. ${ }^{6}$ Ehhez jön hozzá az igen gazdag életút- és kapcsolattörténeti adatokat tartalmazó (kéziratos és nyomtatott formában fennmaradt) alkalmi írások csoportja, amely dokumentumok szintén számos esetben egészítik ki az ismereteinket, és használhatók fel kontrollforrásként az előbb említett forrásokkal szemben.7 Tehát egy nagyon alapos, egymást kiegészítő, egymást ellenőrző primer és szekunder forráskorpusz áll rendelkezésünkre a vizsgált társadalmi csoport vonatkozásában. A kérdésben való tisztánlátás pedig lehetőséget nyújtana arra, hogy pontosabban lássuk a korabeli szászok városvezető családjainak a karrierútjait, és ehhez viszonyítva érzékelhetővé váljanak az átlagtól eltérő érvényesülési utak is. Mindenekelőtt azonban a betöltendő hivatalokról kell pontos képpel rendelkeznünk.

\section{Brassói hivatalok és tisztviselők}

Brassóban - ahogy más közigazgatási központokban - az egyházi és a városi hivatalok az egyéni karrierút állomásait is jelentették. A tisztviselő családok karrierútja párhuzamos életpályák bejárását mutatja, amelyeknek első állomása az előtanulmányok végzése volt - többségében a város gimnáziumában. ${ }^{8}$ Ezt követően - főként az egyházi értelmiség - külföldi egyetemeken folytatta tanulmányait. Ez az időszak már az egyéni érvényesülés kezdeti lépéseire mutat

5 Ernst Wagner (Hrsg.): Die Pfarrer und Lehrer der Evangelischen Kirche A.B. in Siebenbürgen. I. Band: Von der Reformation bis zum Jahre 1700. Köln - Weimar Wien - Böhlau Verlag, 1998. (Schriften zur Landeskunde Siebenbürgens; 22/1.)

6 Szabó Miklós - Tonk Sándor: Erdélyiek egyetemjárása a korai újkorban 1521-1700. Szeged, JATE 1992 (Fontes Rerum Scholasticarum; 4.); Szabó Miklós - Szögi László: Erdélyi peregrinusok. Erdélyi diákok európai egyetemeken 1701-1849. Marosvásárhely, Mentor Kiadó, 1998.

7 Ezzel kapcsolatosan azonban jelentős módszertani akadályokkal kellett megküzdeni. A sok ezer töredékadat szükségessé tette az adatok kutatásának megfelelő formában történő eltárolását. A módszertanról bővebben lásd az alábbi tanulmánykötet írásait: Ballabás Dániel (szerk.): Hagyományos források, új megközelítések. A digitalizáció kínálta lehetőségek a történeti kutatásokban. Eger, Líceum Kiadó, 2019.

8 Azzal kapcsolatban sincsenek ismereteink, hogy átlagosan mikor kezdték meg itt a gimnáziumi éveiket a brassói diákok. Azonban ha rekonstruálni tudjuk az egyes polgárok születési idejét (a keresztelési anyakönyvekkel, a korabeli naplókkal és az alkalmi nyomtatványokkal), és ezt összevetjük a Honterus Gimnázium anyakönyvével, akkor pontosabb képet alkothatunk erről. Az így végzett kutatás során 61 személy születési idejét és beiratkozási idejét sikerült azonosítani az 1650 és 1750 közötti időszakból. Ezek alapján azt mondhatjuk, hogy az iskola növendékei általában 15-18 éves koruk között iratkoztak be az intézménybe (74\%). A fennmaradó egyharmad részben beszélhetünk olyan diákokról, akik ettől eltértek. Bővebben lásd: Nagy Andor: Érvényesülési stratégiák a brassói szász tisztviselők körében. Kapcsolatháló-elemzés és családrekonstrukció az alkalmi nyomtatványok segítségével. Doktori (PhD) értekezés. Eszterházy Károly Egyetem, 2019. 57-58. 
rá. A peregrinációt követő időszak már a családalapítás és az egyéni karrierek kibontakozásának ideje volt a kora újkori értelmiségiek körében. Bármely életpályát választották is a leendő tisztviselők, kötött életutat kellett bejárniuk.

\subsection{Az egyházi elit}

Az egyházi pályát választó, a peregrinációról hazaérkezett brassói akadémiták karrierútjának az első állomása a Honterus Gimnázium tanári állásának elnyerése volt. Itt többféle pozíciót is betölthettek, amelyek hierarchikusan épültek fel. Ezek sorrendben: adjunctus, collega vagy collaborator, lektor, conrektor és rektor. A tanári pályán töltött évek után választhatták őket Brassó valamely kápolnájának prédikátorává (Prediger), utána pedig a főtemplom diakónusává (Diakon). Ezek a pozíciók előzték meg a lelkésszé (Pfarrer) szentelésüket. Lelkészi funkciót a barcasági káptalan plébániáin töltöttek be: Brassóban és a hozzá közigazgatásilag tartozó 13 barcasági településen. ${ }^{9}$

Brassóban öt plébánián láttak el szolgálatot. A szász város legrégibb temploma az Óváros vagy másképpen a Bertalan városrész (Bartholomä, Bartholomeu) plébániája, a Szt. Bertalan-templom (Bartholomaeuskirche, Biserica evanghelică Sf. Bartolomeu) volt. Az erődtemplom már egészen korán, a Német Lovagrend Barcaságba való letelepedését követően, az 1220-as években megépült a Hosszú utca (Langgasse, Strada Lungă) végén. ${ }^{10}$ A másik a Szt. Mártontemplom (Martinsberger Kirche, Biserica Sfântul Martin), amelyik a róla elnevezett hegyen, a Márton-hegyen, valamint a Fellegvár nyugati oldalában, a Közép utca (Mittelgasse, Strada de Mijloc) fölött áll ma is. ${ }^{11}$ Alapítási ideje nem ismert, azonban első okleveles említése 1395-ből való. ${ }^{12}$ Itt volt a Honterus Gimnázium kertje is, ahol a tanulók a gyülekezeteiket tartották. ${ }^{13}$ A következő két templom a középkorban már szintén létezett, de mára elbontották, illetve átépítették. Az egyik az Ispotály-templom (Spitalskirche) volt, amely Brassó belvárosában

9 A következő településeken: Barcarozsnyó (Râșnov, Rosenau), Barcaszentpéter (Sânt Petru, Petersberg), Botfalu (Bod, Brenndorf), Feketehalom (Codlea, Zeiden), Földvár (Feldioara, Marienburg), Höltövény (Hălchiu, Heldsdorf), Keresztényfalu (Cristian, Neustadt), Prázsmár (Prejmer, Tartlau), Szászhermány (Hărman, Honigberg), Szászmagyarós (Măieruș, Nussbach), Szászveresmart (Rotbav, Rothbach), Vidombák (Ghimbav, Weidenbach) és Volkány (Vulcan, Wolkendorf).

10 Erich Jekelius [et al.]: Das Burzenland. Kronstadt. Kronstadt. Verlag Burzenländer Sächs. Museum 1928. 108.; Christof Hannak: Die alten Kronstädter Gassennamen. In: Harald Roth (Hrsg.): Kronstadt. Eine siebenbürgische Stadtgeschichte. München. Universitas Verlag 1999. 277.

11 Gernot Nussbächer: Bástyák, árkok, várfalak. Séta a középkori Brassóban. [Kronstadt], Aldus 2005. 23.; Orbán Balázs: A Székelyföld leírása. Történelmi, régészeti, természetrajzi s népismei szempontból. 6. kötet. Budapest. Tettey Nándor és Társa Bizománya 1873. 329.

12 Gernot Nussbächer: Aus Urkunder und Chroniken. Beiträge zur siebenbürgischen Heimatkunde. Bd. 14. Kronstadt Zweiter Teil. Kronstadt. Aldus Verlag 2014. 140.

13 A forrásokban gyakorta "Mons Gymnicus" alakban fordul elő a templom megnevezése. Lásd még: Nussbächer, G.: Bástyák, árkok, várfalak i. m. 23. 
(Innere Stadt, Braşovul vechi), a régi ispotály mellett állt, az Ispotály vagy Kórház utcánál (Spitalsgasse, Strada Postăvarului). Két utcával távolabb pedig a Szt. János-templom (Johanniskirche, Biserica Sf. Ioan) állt, az evangélistáról elnevezett Szt. János utcában (Johannisgasse, Strada Sfântul loan). Ezek a templomok a város kisebb templomainak sorába tartoztak. Brassó főtemploma azonban a messze földön híres Fekete-templom (Schwarze Kirche, Biserica Neagră) volt. Az épület a 14. század végétől kezdődően, közel egy évszázadon át épült. Nevét az 1689-es tủzvész kormos falai után kapta, amikor a templom nagy része leégett. ${ }^{14}$ Itt szolgált a város mindenkori főlelkésze (Stadtpfarrer) is. A fópásztorok névsora már ismeretes a kutatók körében, ${ }^{15}$ azonban az egyházi hierarchiában az alacsonyabb fokozattal rendelkező prédikátorokra nem fordult még kellő figyelem. A lelkipásztorok szolgálati idejük szerinti csoportosítása jól szemlélteti, hogy míg a város kisebb templomaiban egy-egy prédikátor volt kinevezve, addig a főtemplomban a városi lelkész mellett öt prédikátor segédkezett. Ők tartották a napi istentiszteletet, keresztelték az újszülötteket, és ők temették el a városi társadalom megbecsült méltóságait is. ${ }^{16}$

\subsection{A városvezetői elit}

A város világi hivatalainak ranglétráját bejáró szász fiatalok a gimnáziumi éveik után - a rendelkezésre álló hivatal- és kapcsolattörténeti forrásokban - a húszas éveik elején jelennek újra meg. Az életüknek fiatalabb éveiben a céhek általános vándorútját járták végig, amely az alapvető foglalkozásukkal kapcsolatos ismereteik megszerzését jelentette. Elsőként azonban a házassági adataik, majd a városban betöltött hivatalaik nyomán válnak nyomon követhetővé.

14 A templom történetéről bővebben: Ernst Kühlbrandt: Die ev. Stadtpfarrkirche A. B. in Kronstadt. 1. Heft. Kronstadt. Honterusdruckerei Johann Gött's Sohn 1898. 5-52.; Ziegler Ágnes: A brassói Fekete templom - reformáció és renováció. Brassó - Budapest. Martin Opitz Kiadó, 2018. 27-103.

15 Joseph Trausch: Geschichte des Burzenländer Capituls. Kronstadt. Johann Gött 1852. 75-77.; Gernot Nussbächer: Kronstädter Stadrichter, Stadthannen und Bürgermeister. In: Harald Roth (Hrsg.): Kronstadt. Eine siebenbürgische Stadtgeschichte. München. Universitas Verlag 1999. 293.

16 A felsoroltakon kívül Brassóban több, eltérő felekezetekhez tartozó templom is múködött, mint például a Szt. Miklós-templom (Nikolauskirche, Sfântu Nicolae), amely Bolgárszeg (Obervorstadt, Şchei) görögkeleti egyházközösségének temploma volt, vagy a brassói magyar evangélikusok temploma Bolonya (Blumenau, Blumena) városrészben. A város templomainak sora a későbbiekben pedig bővült még. Meg kell említenem azt is, hogy a 17. században működött magyar evangélikus közösség is Brassóban, azonban velük a jelen értekezésben nem foglalkozom. Binder Pál (19351995) ez irányú kutatásai azonban hiánypótlóak e téren. Lásd: Binder Pál: Az erdélyi magyar evangélikus egyházközségek és iskolák története és névtára (1542-1860). Brassó. [s. n.] 1993.; Binder Pál: Brassói magyar krónikások és barcasági evangélikus egyháztörténészek (1550-1800). Szecseleváros, [s. n.], 2000. 
A város közigazgatási múködésének bemutatásánál mindenekelőtt azt érdemes megjegyezni, hogy a II. András 1224. évi kiváltságlevelében (Andreanum) biztosított jogok ${ }^{17}$ 1422-től már érvényesek voltak a Barcaságra is. A későbbiekre nézve azonban alapvető jelentőségű volt I. Mátyás (ur. 14581490) azon rendelkezése, mellyel 1486-ban létrehozta a Szász Universitast (Universitas Saxonum, Nationsuniversität) - ezzel pedig Erdély valamennyi szászok által lakott településére kiterjesztette az Andreanum hatáskörét. A Szászföld önkormányzatának legfelsőbb szintjén az Univesitas vagy másként a Szász Nemzeti Egyetem intézménye állt. A legfelsőbb szász hivatalnok, a szász nemzet grófja vagy másként ispánja (Comes Nationis Saxonicae) volt, aki közvetlen függésben állt a fejedelemtől. A nemzetet általánosan érintő ügyekben azonban szabadon és függetlenül dönthetett. Mellette müködött egy 22 tagú testület is, amely a városok, székek és körzetek gyúléseinek képviselőiből állt össze. Ez a közel kéttucatnyi ember felelt a Királyföld igazgatásáért, az igazságszolgáltatásért és politikai kérdésekben a szász nemzet nevében foglalt állást. ${ }^{18} \mathrm{~A}$ politikai ügyek intézése azonban a különálló körzetek és magisztrátusok képviselőinek volt a feladata. A megfelelő ügyvitelért a mindenkori legfőbb hivatal vezetője - a szász ispánt követően -, a polgármester volt felelős. ${ }^{19}$ Polgármesterség azonban még a nagyvárosok közül sem mindenhol müködött. Nagyszeben (Hermannstadt, Sibiu), Segesvár (Schäßburg, Sighișoara), Medgyes (Mediasch, Mediaș), Kőhalom (Reps, Rupea) és Nagysink (Groß-Schenk, Cincu) városaiban létezett, de Brassóban és Besztercén (Bistritz, Bistrița) nem - vagy csak rövid ideig múködhetett ez a tisztség. ${ }^{20}$ Ezeken a helyeken a feladata beolvadt a fennálló hivatalokba.

Gernot Nussbächer (1939-2018) brassói helytörténész kutatásaiból képet kapunk Brassó és a Barcaság közigazgatási hivatalainak első megjelenéseiről is: az esküdt polgárokból álló városi tanácsot a bíróval együtt (iudex et iurati) 1358-ban említik először, ${ }^{21}$ míg a városvezetés legfőbb hivatalát betöltő sze-

17 A rendelkezés kijelölte a földjük határait (Szászvárostól Barótig), rögzítette a jogaikat és kötelességeiket, valamint a telepeseket egységesen a szebeni ispán joghatósága alá helyezte (akit a király nevezett ki). Az itt élók szabadon választhatták papjaikat, a bíráikat, szabad vásártartást és kereskedelmet élveztek, és a kihalással megüresedő birtokok királyi eladományozás nélkül visszaszálltak a közösségre.

18 Szirtes Zsófia: Az erdélyi szászság érdekérvényesítése az átmeneti korszakban (16901711). Pázmány Péter Katolikus Egyetem. Doktori (PhD) értekezés 2015. 62-63.

19 Raimund Friedrich Kaindl: Geschichte der deutschen in den Karpathenländern. Gotha. Perthes 1907. 290.

20 Georg Eduard Müller: Stühle und Distrikte als Unterteilungen der SiebenbürgischDeutschen Nationsuniversität (1141-1846). Herrmannstadt. Krafft et Drotleff 1941. 31.

21 Gernot Nussbächer: Brassó és a Barcaság közigazgatása a koraújkor küszöbén. In: Aetas. Történettudományi Folyóirat. (26) 2011/2. 170-177.; Franz Zimmermann - Carl Werner: Urkundenbuch zur Geschichte der Deutschen in Siebenbürgen II. Hermannstadt 1897. nr. 736., 152-153. 
mély, a városbíró (Stadtrichter)22 megnevezést 1360-ban találjuk meg elsőként a forrásokban. ${ }^{23}$

A városbíró széles körủ jogokkal volt felruházva a városi igazgatás és a törvényhozás terén, amely hivatalt a tanácsurak sorából kiválasztott városgazda nyerhette el. ${ }^{24} \mathrm{~A}$ személyéről évente szavaztak, aki aztán meghatározhatta a város által követett irányvonalat és az ahhoz kapcsolódó diplomáciai tevékenységet is. Jellemzően a közösség leggazdagabb és legnagyobb befolyással bíró tagjaiból kerültek ki e hivatal tisztviselői, ugyanúgy, ahogy az ezt követő második hivatalnok, a városgazda vagy másként a folnagy (Stadthann) ${ }^{25}$ is. ${ }^{26} \mathrm{~A}$ városgazdának a különböző időkben eltérő kötelezettségei voltak: hol a rendőri közigazgatás ellátásáért, hol a város és a vidék gazdasági ügyeiért és az adók beszedéséért felelt. Gyaníthatóan ahol nem volt polgármesterség, ott annak a feladatait is a városgazda hivatala látta el. Brassóban az elnevezés első említését az 1353-ból származó kiváltságlevélben találjuk. ${ }^{27}$ A hivatal viselőinek eleinte bírói jogosultságaik is voltak, de később már csak a város gazdasági ügyeit irányították. A két legfőbb tisztség betöltői szinte teljhatalommal járhattak el a város dolgaiban, egyúttal joguk volt beleszólni a város két döntéshozó testületének munkájába, a városi vagy belső tanácsba és a százak tanácsa vagy más néven a külső tanács dolgába.

A városi közigazgatás működését a belső tanács (Magistrat) ellenőrizte, amelynek tagjait (Ratherr) ${ }^{28}$ minden évben karácsony és újév között a saját soraikból választották újra - a legkiválóbb és legalkalmasabb férfiak (würdigste und fähigste Männer) közül. ${ }^{29} \mathrm{~A}$ szakirodalom szerint a szász városokat általában 12 esküdt polgár, míg Brassót 16 fó képviselte a városi tanácsban - minden negyedre 4 képviselő jutott. ${ }^{30}$ Ők szavazták meg a város két legfőbb tisztségét

22 További elnevezései: Richter, Stadt- und Distriktrichter, Oberrichter, magister civium, Bürgermeister, judex, judex primarius.

23 Franz Zimmermann - Carl Werner: Urkundenbuch i. m. nr. 1259A., 755-756.

24 Amennyiben a választás nem az előző évi bíróra esett, az alábbi megnevezéssel illeték: Altrichter, Mitrichter, Stellenvertreter, Projudex.

25 További elnevezései: Honn, villicus, constitutus villicus, Questor.

26 Cziráki Zsuzsanna: Az erdélyi szászok története. Erdélyi szász irodalomtörténet. Kozármisleny. Imedias Kiadó, 2006. 104-105.; Cziráki Zsuzsanna: Autonóm közösség és központi hatalom. Udvar, fejedelem és város viszonya a Bethlen-kori Brassóban. Budapest. ELTE, 2011. 37. (Udvartörténet kötetei; 3.)

27 Franz Zimmermann - Carl Werner: Urkundenbuch i. m. nr. 677.; 93-96.

28 További megnevezései: Senator, Ratgeschworner, Geschworene magister, comes consul, cives juratus. Rangban az első volt az „Aelteste” vagy "Senior” megnevezésű szenátor.

29 Stenner, F.: Die Beamten der Stadt Brassó i. m. V. Ahogy a patríciusságnak, a városi hivatalokba való beválasztásnak is alapfeltétele volt a polgárjog.

30 Mika Sándor: Weiss Mihály 1569-1612. Egy szász államférfiú a XVII. századból. Budapest. Magyar Történelmi Társulat, 1893. 20-24.; Granasztói György: Társadalmi tagozódás Brassóban a XV. század végén. In: Századok. 1972/2. 395.; Nussbächer, G.: Brassó és a Barcaság közigazgatása i. m. 172.; Maja Philippi: Die Bürger von Kronstadt im 14-15. Jahrhundert. Bukarest. Kriterion, 1986. 131. 
betöltő személyeket is, akiknek megválasztásuk előtt (december 26.) a munkájukról való számadási kötelezettségüknek is eleget kellett tenniük. ${ }^{31}$ Ezután került sor a tanácsurak megválasztására, akik a város politikai és gazdasági ügyeiről - szavazattöbbséggel - döntöttek. Az ő kötelességük volt, hogy felügyeljék a polgári és büntetőjogi ügyek jogszerűségét, a rend fenntartását Brassó és a környező barcasági települések területén is. Ők vetették ki a rendes és a rendkívüli adókat, és feladatuk volt, hogy jogos arányosságban kimérjék a hadjáratok során teljesítendő katonai szolgálatot is.

A kora újkori Erdélyben megkülönböztetett státusznak örvendett a városi jegyző (Notär), aki nem csupán a városi iratokat állította ki, hanem jogi képviselő is volt. Ő értelmezte és adta elő a törvényeket, illetve felügyelte a tanácsülések menetét is. ${ }^{32}$ Nem volt ritka, hogy egy-egy képzettebb nótárius megszerzéséért versenybe is szálltak az erdélyi városok. Brassóban a hivatal betöltése egy szűk körre korlátozódott, mert rendszerint a várost vezető családok tagjai közül kerültek ki a megválasztott személyek, akikből később majdnem minden esetben a város vezetői is váltak. ${ }^{33}$

A belső tanács befolyása alatt áll a város külső tanácsa vagy más néven a százak tanácsa. Brassó esetében a százatyák (Hundertmannschaft) ${ }^{34}$ intézménye a 15. században alakult ki. Első írásos említésük 1495-ből való. ${ }^{35}$ A testület 100 tagja elsősorban a középréteget alkotó városi kereskedők, valamint a céhekben egyesült iparüző polgárok közül került ki. A város negyedeiből 25-25 fő került kiválasztásra, akiket a belső tanács nevezett ki. A százatyák választották a főtiszteket, a bírót és a folnagyot, ők ellenőrizték a városi számadáskönyveket, továbbá a városi statútumok szövegezésében is részt vettek. Üresedés esetén a városi tanács jelölte ki az új tagot, de a hivatalviselők tisztségüket halálukig megtarthatták. A százak tanácsának elöljárója volt a szószóló (Orator Centum virorum), ${ }^{36}$

31 Az újra meg nem választott városgazdát külön tisztséggel illeték, amelynek elnevezései: Althann, Mithann, Provillicus, Proquaestor.

32 Flóra Ágnes: A kora újkori kolozsvári elit portréja. In: Urbs. Magyar Várostörténeti Évkönyv. III. Budapest. [s.n.], 2008. 137-138.; Flóra Ágnes: Hivatal vagy hivatás? Városi jegyzők a kora újkori Erdélyben. In: Dáné Veronka - Oborni Teréz - Sipos Gábor (szerk.): „... éltünk mi sokáig 'két hazában'...”. Tanulmányok a 90 éves Kiss András tiszteletére. Debrecen. Debreceni Egyetemi Kiadó, 2012. 123-134.

33 Brassó 16. századi jegyzője volt (a nevük után az életük végén viselt pozíciókat tüntetem fel): Matthias Fronius (1522-1588) városbíró, Bartholomäus Fuchs (?-1591) barcaföldvári lelkész, Valentin Heltner (?-1590) városbíró. 17. századi jegyző volt többek között Michael Weiss (1569-1612) városbíró, Christian Benckner (?-1615) szószóló, Andreas Gorgias (?-1633) városbíró, Martin Schneeweiss (1600-1646) városgazda, Michael Closius (?-1660) szenátor, Joseph Boltosch (1615-1661) városbíró, Simon Draudt (1647-1693) városbíró, Georg Czako (1661-1726) városgazda. Vö. Stenner, F.: Die Beamten der Stadt Brassó i. m. 1916.

34 Továbbielnevezései:communitas centumvirorum, StadtKummunität, Wahlbürgerschaft.

35 Müller, G. E.: Stühle und Distrikte i. m. 76.

36 További elnevezései: tribunus, senior centum virorum, Kommunitäts-Orator, Vormund, Hundertmann-Wortmann. 
aki ellenőrizte a közösség ügyeinek keresztülvitelét, és részt vehetett a belső tanács gyűlésein is. ${ }^{37}$ Ezek a tanácsosok egyidejűleg a különféle céhek biztosai (Inspektor) is voltak. ${ }^{38}$

Aki a városi tanácsba pályázott, annak saját házzal kellett rendelkeznie. Ha ezzel nem rendelkezett, nem jutott be, még akkor sem, ha az érdemei magukért beszéltek. Ha valaki tanácstaggá válhatott, a kötelességek teljesítéséről esküt kellett tennie, amelyet a külső és a belső tanácsba történő belépéskor is ki kellett nyilvánítania. Az esküvel a jelöltek egyúttal hűségükről is biztosították a tanácsot. ${ }^{39}$

A hivatali előmenetel, amint azt az előbbiekben láttuk, kötött volt: a bírót a volt városgazdák, a városgazdát pedig a tanácsurak közül választottak, kizárólag a város „patríciusi", elit rétegéből. Ugyanakkor még ezek a legmagasabb hivatalok sem biztosítottak olyan fizetést, amely elegendő lehetett volna a meggazdagodáshoz, ezért a vagyon mindenképpen előzménye és nem következménye volt a hivatalviselésnek. ${ }^{40}$

\section{A hivatalba lépések átlagos időpontja}

Ahhoz, hogy képet kapjunk arról, hogy a végzett akadémiták átlagosan hány éves korukban töltöttek be tanári pozíciót egykori gimnáziumukban, egyszerü számítást kell végeznünk: a hivatal betöltésének éve és az adott személy születésének időpontja közötti különbséget kell kiderítenünk. Kutatásom során 66 olyan személyt sikerült regisztrálnom, akiknél mindkét év kétséget kizáróan adatolható volt. Az így kapott eredmények szerint a legfiatalabbak 21 éves koruktól töltöttek be lektori állást a gimnáziumban, ${ }^{41}$ míg a legidősebb

37 Cziráki Zs.: Autonóm közösség és központi hatalom i. m. 38.

38 A középvezetők hozzá voltak rendelve a város különböző részlegeihez azért, hogy a szükséges feladatokat ellássák. Ilyen módon ezeket különböző megnevezésekkel is illették, így voltak elnöki (Praesidial), törvényszéki (Gerichts-), városi (Kommunitäts-), rendvédelmi (Polizei), hagyatéki (Divisorats-), titkársági (Sekretär), bírósági fogalmazó (Aktuar) és jegyzői (Notär) tisztségek. A magyar és román nyelvre való fordításról a fordító (Translator vagy scriba Hungaricus, scriba Wallachicus, wallachischer Schreiber) gondoskodott. A hivatali dokumentumok - pl. akták, protokollok, oklevelek és egyéb hivatali iratok - nyilvántartása és megőrzése a levéltáros (Archivar, Registrant) feladata volt. A városi és közösségi adók kiméréséről és behajtásáról a közigazgatási részlegek hivatalai gondoskodtak: Steuer-Einnehmer, Perzeptor regius, königlicher Perzeptor, Kontributions-Kollektor. Bővebben a brassói tisztviselőkről lásd: Stenner, F.: Die Beamten der Stadt Brassó i. m. III-XI.

39 Stenner, F.: Die Beamten der Stadt Brassó i. m. V.

40 Cziráki Zs.: Az erdélyi szászok története i. m. 104.

41 Stephan Gottlieb Fronius (1718-1751) 1739-ben (Vö. Szabó M. - Szögi L.: Erdélyi peregrinusok i. m. nr. 1247) és Georg Clompe (1723-1782) 1744-ben (Vö. Szabó M. - Tonk S.: Erdélyiek egyetemjárása a korai újkorban i. m. nr. 671). 
48 éves korában. ${ }^{42} \mathrm{Az}$ említett 66 fő hivatalba kerülésének átlagát nézve azt mondhatjuk, hogy 31 éves koruk idején kerültek lektori pozícióba. Ettől korábban, sőt a legfiatalabban, 23 évesen, Johann Albrich (1663-1690) töltötte be ezt a státuszt. Őt követi David Czako (1641-1681), Johannes Honterus (16331691) és Johann Fuchs (1631-1686) mindössze 26 évesen, Valentin Greissing (1653-1701) 27 évesen, Marcus Draudt (1665-1724) és Andreas Kraus (16681751) 28 évesen, Marcus Fronius (1659-1713) pedig 31 évesen. Az említett személyek életpálya-alakulásai és családi kapcsolataik további kutatást tesznek szükségessé az átlagtól eltérő érvényesülésük megválaszolásához. Egyúttal érdemes arra is figyelemmel lenni, hogy a további pozíciók betöltésében is ők emelkednek-e ki?

A hivatali ranglétrán a következő állomás a prédikátorrá való kinevezés volt. A pozíció betöltésének az átlagos életkorát is az előbbi számítás alapján deríthetjük ki. Ebben a körben összesen 53 személy születési és lelkipásztori kinevezését sikerült forrásokkal alátámasztanom. Az eredmények alapján azt mondhatjuk, hogy 37 év volt az átlagos életkora a gimnáziumi katedráról való előléptetésnek. A legfiatalabb személy mindössze 22 évesen lett prédikátor, ${ }^{43}$ míg a legidősebb 51 évesen. ${ }^{44}$ Az előző bekezdésben megismert személyek szintén előkerülnek: Johann Fuchs (1631-1686) 28 évesen, Marcus Draudt (1665-1724) 30 évesen, Marcus Fronius (1659-1713) 33 évesen, Andreas Kraus (1668-1751) 35 évesen, míg David Czako (1641-1681) 38 évesen lett brassói prédikátor. ${ }^{45}$ Összességében elmondható, hogy itt is az átlagnál előbb léptek prédikátori pozícióba.

Barcasági lelkészi kinevezést elértek és pontos születési évvel rendelkezők 51-en vannak a kutatásom tanúsága szerint. Az átlagot nézve 44 évesen kerül-

42 Martin Rauss (1643-1712), aki a korabeli források szerint alig volt másfél éves, amikor egy betegségben elvesztette a szeme világát (Vö. AHG IV F1 To 206/II.). Mindez azonban nem akadályozta meg abban, hogy tanuljon. 1660-ban járt a Honterus Gimnáziumba (Vö. Wagner, E.: Die Pfarrer und Lehrer i. m. nr. 2861.). Szorgalmával tekintélyes tudásra tett szert teológiából, és külföldi egyetemlátogatás nélkül 1691ben gimnáziumi tanárrá nevezték ki. 1694. május 24-én prédikátorrá szentelték a Szt. János utcai templomban, 1696. március 12-én pedig áthelyezték a Szt. Mártontemplomba, ahonnan már nem küldték el haláláig - amiben talán a szembetegsége is szerepet játszhatott. Megjegyzik vele kapcsolatban, hogy tekintélyes könyvtárat gyűjtött össze, amelynek a tartalmát is igen jól ismerte azáltal, hogy könyvei szövegét felolvastatta magának. A prédikációit mindig lediktálta valakinek, majd visszaolvastatta, hogy az emlékezetébe vésse az istentiszteletek tartásához. A róla szóló írások szerint beszédeit csodálattal hallgatták a hívek. 1712. április 16-án hunyt el Brassóban. Vö. Joseph Trausch: Schriftsteller-lexikon oder biographisch-literärische Denk-blätter der Siebenbürger Deutschen. I-III. Bd. Kronstadt. Verlag von Johann Gött et Sohn Heinrich, 1868-1671. III. 83.

43 Ez alkalommal is Stephan Gottlieb Froniust (1718-1751), majd őt követi Georg Clompe (1723-1782), Georg Closius (1630-1696) és Johann Gockesch (1649-1686) 24 évesen.

44 A legidősebb életkort betöltő továbbra is Martin Rauss (1643-1712) volt.

45 Johann Albrich (1663-1690) azonban már nem érhette meg a kinevezését. 
tek lelkészi pozícióba. ${ }^{46}$ A már ismert nevek itt is előfordulnak: Johann Fuchs (1631-1686) 32 évesen, Marcus Fronius (1659-1713) 36 évesen, Marcus Draudt (1665-1724) 41 évesen, Andreas Kraus (1668-1751) 44 évesen vált lelkésszé: azaz mind az átlagnál gyorsabban. Külön érdemes megemlíteni, hogy a korabeli előmeneteltől eltérő módon már a gimnáziumi rektorsága után, 41 évesen választották meg Valentin Greissinget (1653-1701) Barcarozsnyó lelkészének. A reformátor ükunokáját, Johannes Honterust (1633-1691) szintén - életkorát tekintve néhány évvel később (45 évesen) - azonban Brassó főlelkészének választották meg (!) egyenesen a rektori pozícióból. Feltételezhető, hogy mindezek a városban őket megillető tekintélyt is jelzik (ami felveti a város vezetőségével való rokoni kapcsolataiknak a kérdését is).

Az egyházi elit pályájának tetőpontját, a barcasági esperesi kinevezést is meg kell említeni, amit a korabeli források kiértékelése során 48-tól 79 éves kor között töltöttek be (13 esperes megfigyelése alapján). ${ }^{47}$ Átlagosan 62 éves korban kezdték meg a hivatalt.

A város politikai elitje kapcsán szintén a négy legfontosabb hivatalt (szenátor, jegyző, városgazda és városbíró) kívánom bemutatni abból a szempontból, hogy a pozíciókat átlagosan hány éves korukban töltötték be a vizsgált személyek. Ahogy az előbbiekben már szó esett róla, a város magisztrátusába a külső vagy százak tanácsából lehetett bekerülni. Pontos születési és hivatalba lépési adatot 69 szenátor körében regisztráltam. A legfiatalabb 23 évesen, ${ }^{48}$ míg a legidősebb 56 évesen került a város belső tanácsába. ${ }^{49}$ Átlagosan azonban azt mondhatjuk, hogy 38 évesen lehetett a korban tanácsúrrá válni. A város jegyzői (Notär) feladatait ellátók között nyolc főt találtam, akik körében a hivatalba lépés átlagos időpontja 38 év volt. ${ }^{50}$ Városgazdai hivatalt 28 fő körében tudtam pontosan adatolni, ahová 38-tól 59 éves korig találhatunk hivatalba lépőket. ${ }^{51}$ Átlagosan pedig 50 évesen kerültek ebbe a pozícióba. Végezetül a városbíró hivatalát betöltők közül 17 főt regisztráltam pontos születési és első hivatalba lépési dátummal. Ők a 41. és a 62. életévük között kezdték meg a hivatali idejüket, míg átlagosan 52 év volt a bekerülés életkora ebbe a pozícióba. Az eddig leírtakat a következő táblázatban foglalhatjuk össze.

46 A rendkívül gyors hivatali életpályát befutó Stephan Gottlieb Fronius (1718-1751) ezúttal is az első a maga 23 életével. Őt követi Georg Cloisus (1630-1696) 29 évesen.

47 Legfiatalabban Marcus Fronius (1659-1713) 48 évesen, míg Daniel Croner (1656-1740) 79 évesen.

48 Simon Draudt (1703-1736) városkapitány (Stadthauptmann).

49 Valentin Plecker (1673-1734) súlymérő (Wagemann) és piacbíró (Marktrichter).

50 Legkorábban Georg Czako (1661-1726) és Georg Draudt (1654-1691) 30 évesen, míg legidősebben Andreas Enyeter (1672-1745) és Martin Seewald (1660-1721) adatolható (49 évesen).

51 Legfiatalabban Simon Draudtot (1647-1693), mindössze 38 évesen, míg legidősebben Bartholomäus Hirschert (1622-1682) és Caspar Rausst (1613-1674) találtam, 59 évesen. 


\begin{tabular}{|l|l|l|l|}
\hline Egyházi elit & Átlagos életkor & Városvezetői elit & Átlagos életkor \\
\hline Lektor & (21-48) 31 év & Szenátor & (23-56) 38 év \\
\hline Prédikátor & (22-51) 37 év & Jegyző & (30-49) 38 év \\
\hline Lelkész & (29-64) 43 év & Városgazda & (38-59) 50 év \\
\hline Esperes & (48-79) 62 év & Városbíró & (41-62) 52 év \\
\hline
\end{tabular}

1. táblázat: A brassói tisztviselők hivatalba lépésének átlagos életkora

\section{3. Összegzés}

Minden jel arra utal, hogy bár az egyéni életúttól függött, hogy ki hogyan haladt előre a hivatali ranglétrán, a családi kapcsolatok és így a tehetősebb felmenők felderítésével további válaszokat is remélhetünk az átlagtól eltérő előrejutásra. Az viszont általánosan elmondható, hogy az egyházi pályára készülők a tanulmányaik befejezését követően tértek haza, és kezdték meg a többségében hat évig tartó gimnáziumi időszakukat. Ezt követően segédlelkészként átlagosan szintén hat évet töltöttek el a város templomaiban, majd a barcasági települések lelkészeiként fejezték be életüket. Közöttük néhányan esperesi méltóságot is viseltek, amelyet a legidősebbek tölthettek be. Ezzel párhuzamosan szenátori és jegyzői feladatokat 38 évesen kezdtek ellátni, míg a város két vezető pozícióját a negyvenes-ötvenes éveikben kezdték meg. A hivatalba lépések vizsgálatának tanúsága szerint a brassói Czako, a Draudt, a Fuchs, a Fronius, a Greissing, a Honterus, a Kraus és a Plecker családok tagjait érdemes külön figyelemmel illetnünk a további karrier- és kapcsolattörténeti kutatásokban.

A későbbiek elemzések során fontos volna megvizsgálni azt is, hogy ezen tisztviselői körön belül miként alakultak az egyes személyek (és velük együtt a családok) közötti presztízs mértéke is. A társadalmi hálózatokkal foglalkozó kutatók úgy tartják ugyanis, hogy a nagyobb presztízzsel rendelkező személyek nagyobb kapcsolati kört tudhatnak magukénak. ${ }^{52}$ Ehhez pedig hozzátehetjük, hogy nagy eséllyel a jelentősebb családokból származó személyekkel köthetnek házasságot, ami az egyéni előrejutásukra, de akár a gyermekeik későbbi pozíciószerzésére is hatással lehet. A dolgozatban kapott eredmények tehát további sejtések és várakozásokkal teli kérdések megfogalmazásához vezetnek el.

52 Kürtösi Zsófia: A társadalmi kapcsolatháló-elemzés módszertani alapjai. In: Takács Károly (szerk.): Társadalmi kapcsolathálózatok elemzése. Budapest. BCE Szociológia és Társadalompolitika Intézet, 2011. 25. 